\title{
Five Examples of Manipulative-Motoric Tasks Utilized For Classwork asan Interactive-Multimedia and Animated Learning Software
}

\author{
Ph. D. Slavoljub Hilčenko ${ }^{1}$
}

\begin{abstract}
The ground basis for this paper is Mayer's model of cognitive multimedia learning theory. Namely, the largest number of learning programs establishes its contact with users only on perceptional modality anent audio and visual communication. However, there is a wide spread acknowledgement that ascertainment draws its grounds from sensomotorics and presents the precondition for regular emotional and social development of children. Therefore the objective of this article is to present five tasks extracted from the ensemble of knowledge purposed for elementary school pupils that equally pays attention onto development of intellectual capabilities and manipulative-motor competences of pupils, as well. Thus, we widen the basis of educational software learning by practical operations(principle of obviousness) that makes this learning model more valuable and purposeful. Essentially it includes complementing Mayer's model by motor learning-manipulation with didactic material, gaining experiences and motor habitudes via proprioceptors of arm and leg muscles and joints. The basic model of multimedia learning is broaden by manipulative-motor learning, manipulation and game that appear "inside and outside" of multimedia presentation.
\end{abstract}

Keywords:instructional design, model of cognitive theory of multimedia learning,manipulative-motor learning, school work, learning and playing "inside and outside" of multimedia presentation.

\section{Introduction}

The anticipations that computers will enter by large into elementary schools of Serbia has come true rather "formally" than "essentially". Namely, most of the schools has facilitated informatics classrooms but the remain unutilized due to (un)known reasons. The whole matter hereby we are interested in from the aspect of schoolwork. At this educational level there is an optional school subject "From a toy to a computer"(starting from the first grade all up to the fourth grade with accompanying textbooks). The content of the subject is prevalently conditioned by the level of enthusiasm and familiarity concerning computer usage of few schoolteachers. Except scarce and (non)qualitative electronic editions in Serbian language purposed for this target group and various schools subjects (mathematics, arts, P.E.) the offer in the market is very poor. Web sites such as: www.lilibi.si, http://www.ixl.comor,www.brainpop.com do not exist in Serbiaand these kind of advance learning accomplishments are yet to be created.

On the other hand, the small number of interactive-multimedia and animated-educational content that are directly related to school subjects and units prevalently communicate on audio-visual platform. Basically it means "watch, listen, think and use the mouse!"

However, there is a wide spread acknowledgement that ascertainment draws its grounds from sensomotorics and presents the precondition for regular emotional and social development of children.Therefore, according to Benjamin Franklin (the face on $100 \$$ bill) words that he said 100 years ago the following conclusion is quite clear:

"Tell me and I will forget; Show me and I may remember;Involve me and $i$ will understand!"

In that sense if "visualize" Mayer's cognitive theory of multimedia learning [3, 4],and additionally adopt the learning characteristics that are inherent to the pre-school children and mostly to elementary school children we come up to the conclusion that we ought to offer them such interactive-multimedia and animatededucational content that suit the nature of their learning abilities and includes not only eyes, eras and hand, but hands, body, heart, head, legs...which leads us to the instructional designer role [17]and the concept of engagement orientated schoolwork.[2].

Presenting the subject, phenomena, processes and behavior at this target group is conveyed directly and indirectly, by showing, presenting and illustrating. [1]:

- Showing implies the procedure a teacher carries out relating children senses with direct content teachers intends to explain,

- Presentingis characterized by the procedure of introducing with substitutions or symbolic replacement of these contents (Venn diagram-presenting assembly), whilst 
- Illustrating symbolizesunderstanding of something circumstantially after somebody presented itpreviouslyhad it tilled artistically and didacticallyby the usage of various audio, visual means or computer (qualitative educational software).

In that respect we created a sequence of interactive tasks that are adjusted to the nature of learning of this particular target group and represent a part of the school subject content of that specific elementary school age group. The presented tasks provide equal importance to the development of intellectual capabilities and manipulative skills of hands + motor abilities of pupils' legs hence broadening the basis of learning with practical work (principle of obviousness) in such a way that enriches this model of learning and contributes to its value.

Essentially it means complementing the basic cognitive model of multimedia learning [3, 4], with motor learning (manipulation with didactic material, gaining experiencesandmotor habitudes via propriceptors within muscles and joints of arms and legs). In its essence this kind of model is extended with practical engagement of pupils that handle didactic material and involve themselves in motor learning [6].

The primary model of multimedia learning is enlarged with manipulative-motor learning, engagement and playing that takes place "inside and outside" of multimedia presentation (Figureno. 1\& 2).

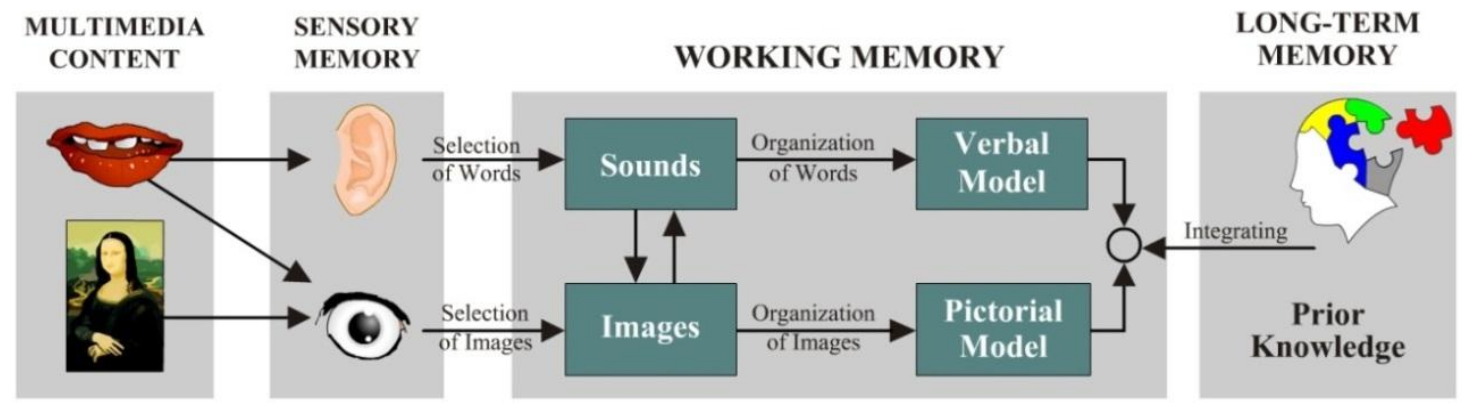

(Figure no.1: Mayer's cognitive model of multimedia learning)

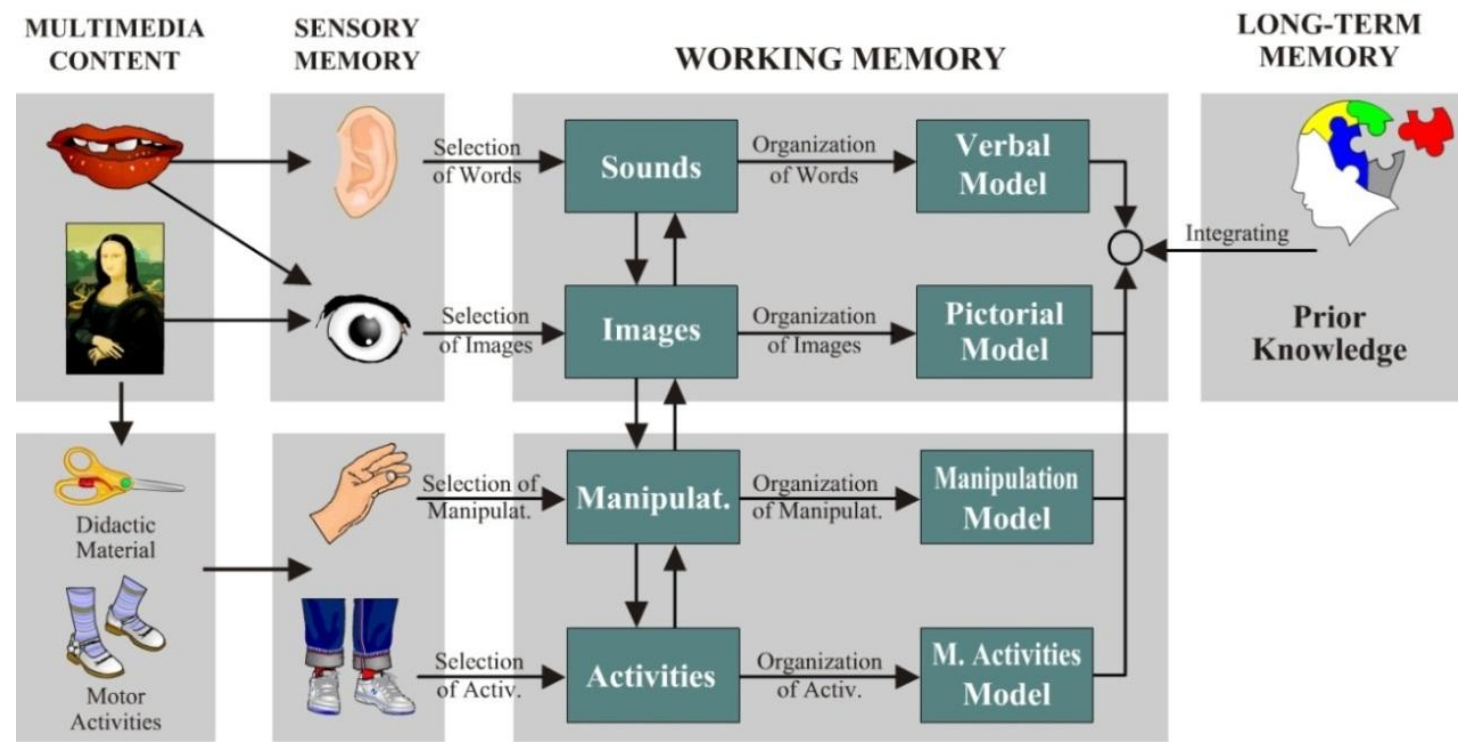

(Figure no.2: Cognitive model of multimedia learning complemented by manipulative-motor learning)

\section{FIVE SubJECTS-Five Examples Of Multimedia Manipulative-Motoric Tasks}

Let us emphasize that all of the application here are in legal version of Macromedia Flash8 program in resolution of $1024 \times 768$ pixels.

It is necessary to stress that this approach, beside the software segment, demands an adequate didactic material and tool as the ancillary material that can be additionally delivered or teachers accompanied by pupils, parents or other can prepare it themselves. Practical manipulative-didactic tasks are basically getting solved before, along or after the application or a solved task has been seen. Therefore, the engagement, learning and play happen "inside and outside" of application that is defined by certain number of steps. The work "outside" 
the application can be upgraded, changed, made more complex and it depends on the idea the teacher developed. The first example is related to the school subject Serbian language and topic: Addressing the envelopes! Besides learning the right way to address the envelopes, to stick stamps in the application then ensues the sequel of learning when pupils practice what they have learned in a concrete task, they write a letter to a real person, together they go to post office where they send it to desired destination... (Pictureno. 1).

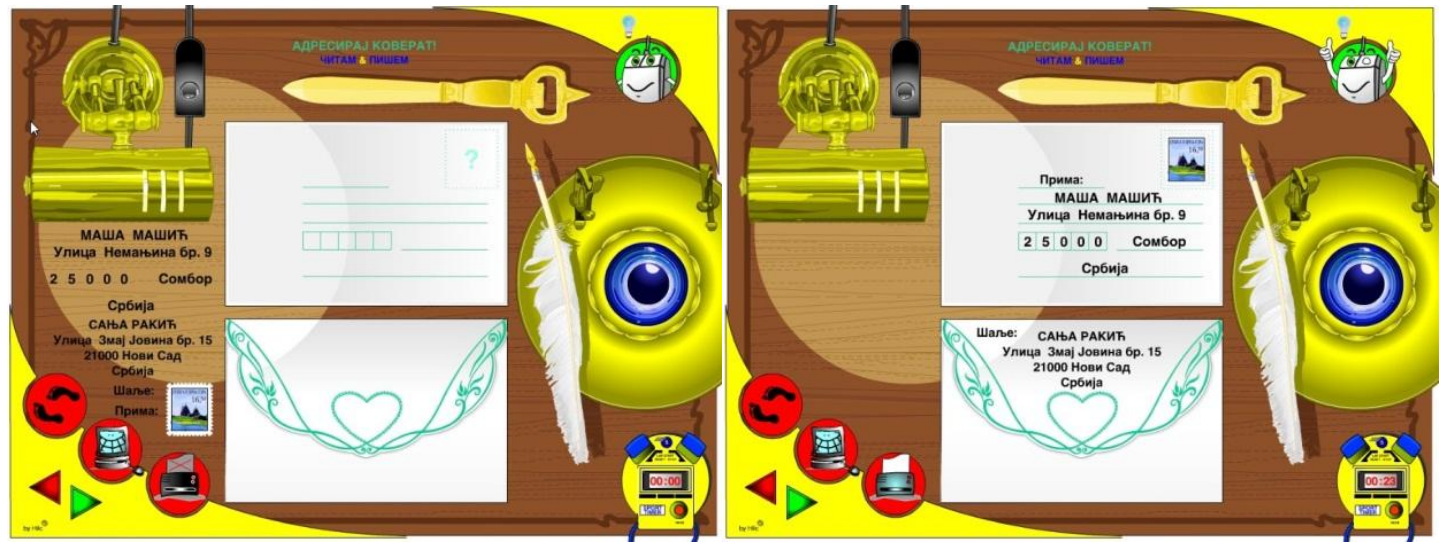

(Pictures no.1: An interactive task from the school subject Serbian language that has its methodical extension "outside of application")

Regarding the other example from Mathematics the order is opposite. Namely, "the step outside of application" precedes the step check within the application. The task from geometry: Cut the cross then assemble a square requires that pupils must think through each and every step (4), before it is checked with the application. The solution is reached by drawing, cutting and searching the solution, assembling the elements by the method of trials and errors. This one just like the previous task includes didactic material and tools that instigate the development of fine motor abilities of hands (picture no.2).
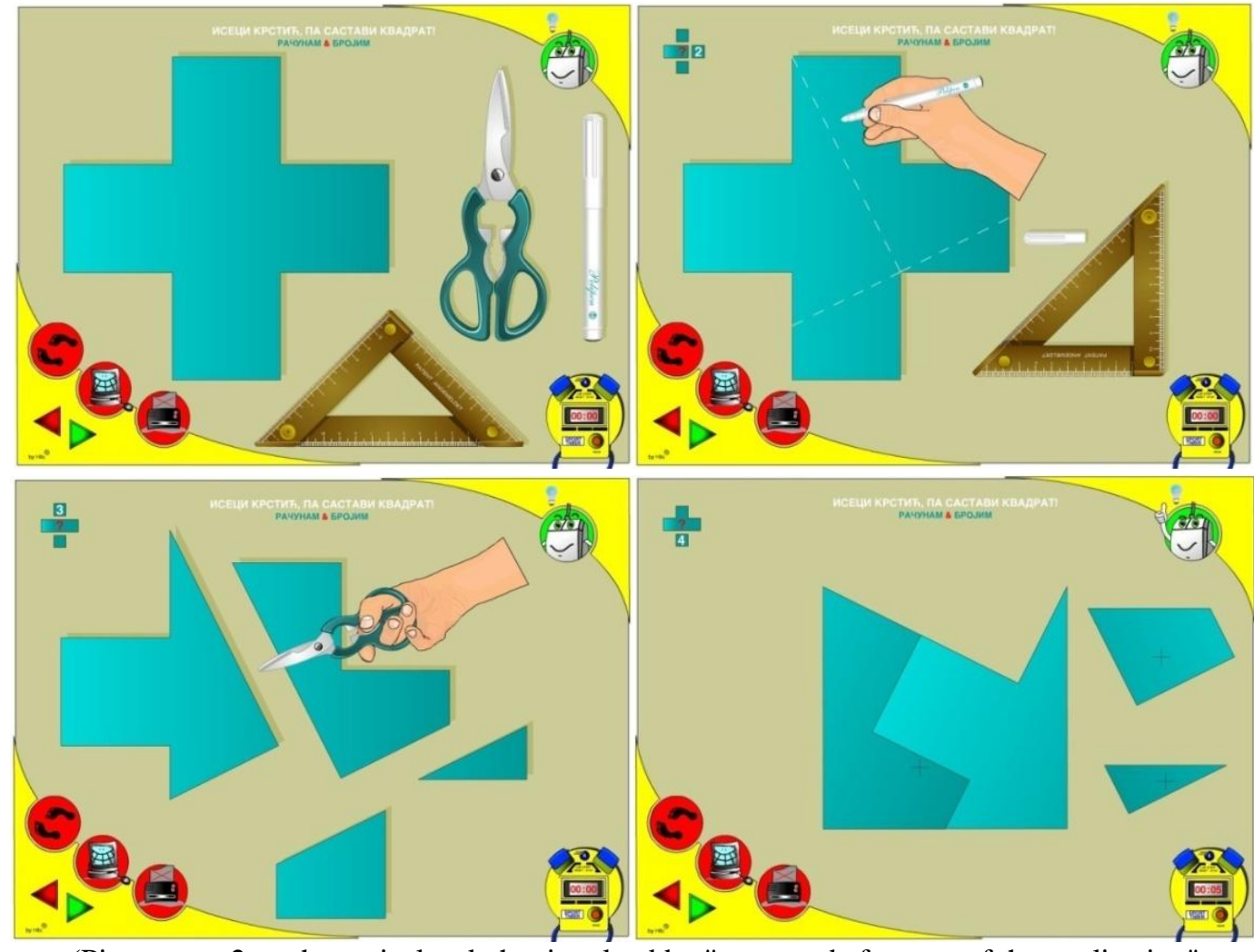

(Pictures no.2:mathematical task that is solved by "one step before out of the application" and it is checked within the application) 
For the task from the school subject: The world around us we found a direct inspiration from the program and method created by Maria Montessori. Practical task such as tying shoe laces represent a problem for the pre school children and the ones in the first grade of elementary school.The recommendation is that as the children are younger this task ought to be learnt simultaneously "inside and outside" of application. (Picture no. 3). Children of the pre school age develop more slowly the fine motor skills comparing to rough motor skills and the first mentioned skills are developed gradually and they become more skilful at drawing, modeling plasticine, sewing etc. For automated learning it is required to do more than 10.000 repetitions! As confirmation of what has been learnt the procedure of solving the application where the act is "divided into 6 steps", can serve the purpose. These steps have to be connected in right order accomplishingthe whole (by clicking the mouse) which leads us to the complete animated presentation of tying shoe laces.
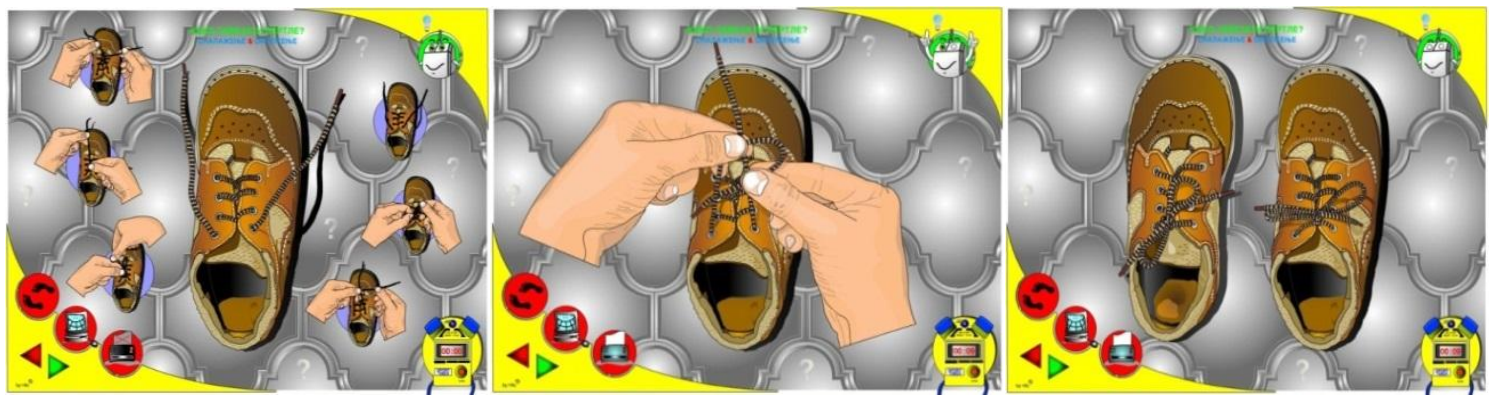

(Pictures no.3:The display of manipulative activity of tying shoe laces)

The character of the school subject Musical education offers a wide range of possibilities for creating manipulative-motor tasks. The fact that this school subject includes playing, singing and composing has inspired us to create the task with the following topic: Play on the wooden xylophone. It comprises the idea where the pupils by following the guidelines step by step, build their instruments by themselves and play it "inside and outside of application". By following the guidelines, in a simple way, the pupils build the instrument and try to play two musical phrases (Picture no. 4). The one who manages it can compose and play ones own composition on a real instrument.

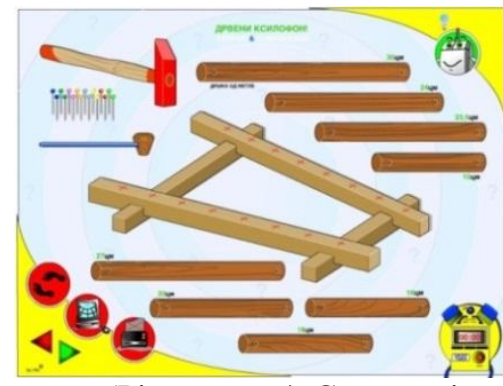

(Picture no. 4: Comparative m
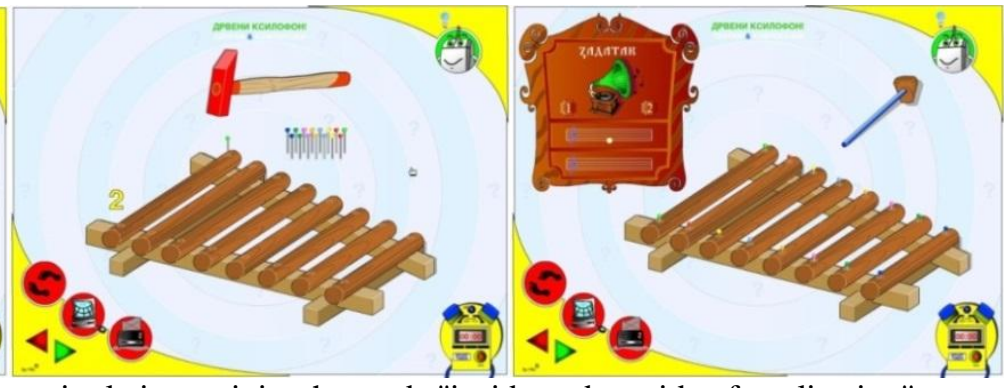

-build a real musical instrument)

As well as at the previous school subject Arts is very instigative regarding the creation of various creative-manipulative tasks. In that sense we wanted to offer an innovative technique of wood carving for the fourth grade pupils. Therefore, the application comprises only the instructions and the order of the steps while the creational work realizes "outside the application"(picture no. 5).
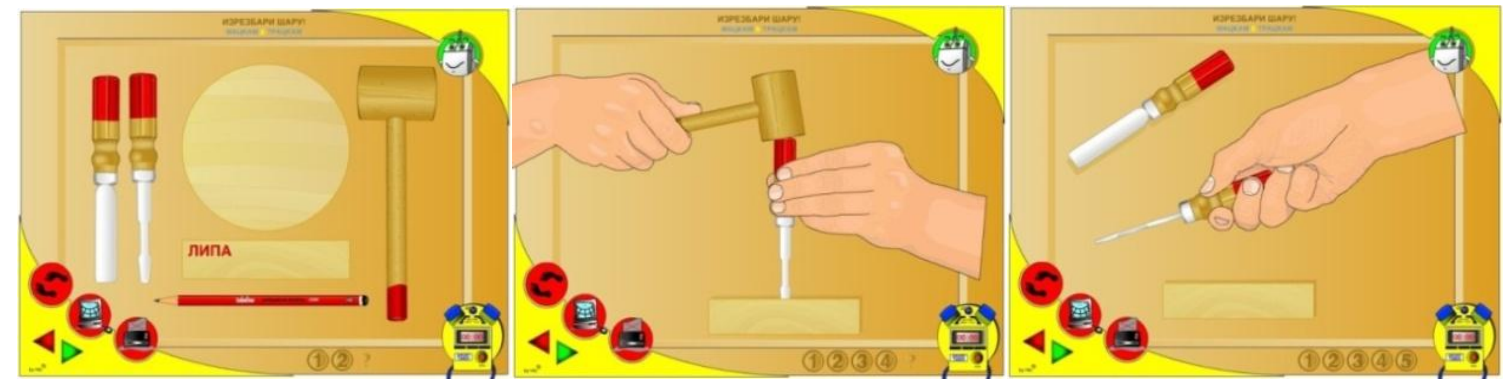

(Picture no.5:The application comprises only the instructions and the order of the steps while the creational work is realized "outside the application") 
The possibility of developing the motor agility of legs we saw at the domain of the school subject Musical education where within the topic: Folk dance accompanied by singing the song"I sowed water melons!" the pupils learn the lyrics and steps of the folk song. The suggested methodical procedure with this application is frontal approach with the use of the video beam projector. First the pupils learn the lyrics then the simple steps all up to "increasingly bigger number of those pupils" who acquired the lyrics and dancing steps. With appropriate organization and enough computers it is possible to organize this class in a smaller number of groups when what has been learnt "is synthesized into the whole" and practice.How well the pupils acquired the steps can be checked within the application (picture no. 6).

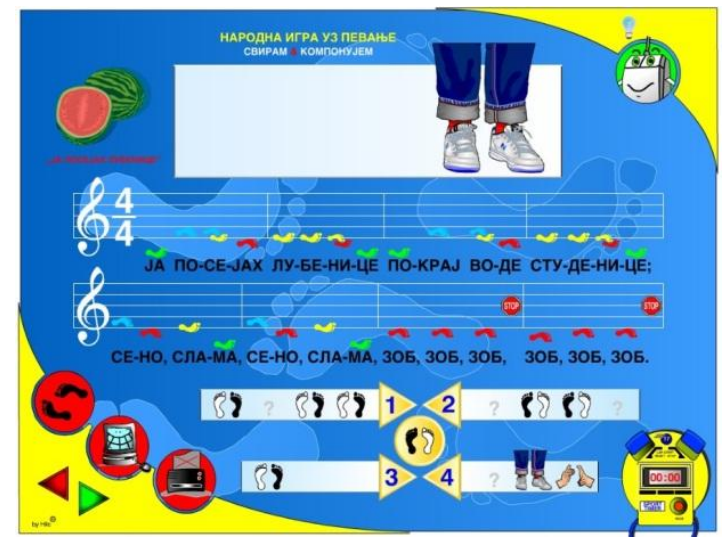

(Picture no.6:Comparative learning inside and outside of application by following the dancing steps guidelines)

\section{Conclusion}

The presented examples of interactive-multimedia and animated-educational tasks that provide as much importance to stimulation the intellectual abilities as it aims the manipulative-motor skills of the pupils, were the way we wanted to stress the high level of autonomy regarding the pupils engagement. Thereby, they provide an individual pace and the realization of the tasks according to the provided instructions in such a manner that pupils can make their own signature of originality whilst solving each and every individual task. Furthermore, the tasks have the functional character in as much they "come out of the real life situations and they have a concrete and practical appliance..."

\section{References}

[1] E. Kamenov, "Metodika", Metodička uputstva za Model B osnova programa predškolskog vaspitanja i obrazovanja dece od tri do sedam godina 1. deo, Odsek za pedagogiju filozofskog fakulteta u Novom Sadu, Novi Sad, 1997

Jank-Meyer, "Didaktische Modelle", Cornelsen, Scritor, Frankfurt am Main, 1994

[3] R. E. Mayer, "Multimedia learning". Santa Barbara: University of California, Cambridge University press 2001

[4] R. E Mayer, The "Cambridge Handbook of Multimedia Learning". New York: Cambridge University Press 2005

[5] S. Hilčenko, "Obrazovni softver kao podsticajno sredstvo u učenju rešavanjem problemsko-logičkih zadataka učenika razredne nastave", Inovacija u nastavi, br. 3/08, str. 62-68, Učiteljski fakultet, Beograd 2008(a)

[6] S. Hilčenko, "Obrazovni softver kao interaktivno manipulativno i motoričko podsticajno sredstvo u razrednoj nastavi", Pedagoška stvarnost, br. 1-2, str. 69-78, Novi Sad, 2008(b)

[7] S. Hilčenko, "Polazne teorijske osnove u razvoju kvalitetnog obrazovnog softvera namenjenog deci predškolskih ustanova", 1. međunarodna stručno-naučna konferencija "Obrazovno-vaspitni procesi u predškolstvu", Visoka škola strukovnih studija za obrazovanje vaspitača Subotica, Zbornik radova, str. 227-242, Subotica 2008(c)

[8] S. Hilčenko, "Multimedijalni obrazovni softver namenjen učenicima u prva četiri razreda osnovne škole", međunarodna konferencija "Budućnost obrazovanja učitelja - Novi izazovi i pregledi", Učiteljski fakultet, Subotica, Zbornik radova, str. 299-304, Subotica, 2009(a)

[9] "Пример компьютерного софтвера, как средства для и зучения сербского языка детей младших классов, которые живут в сербии и заграницей", Международный научный симпозиум «Славянские языки и культуры в современном мире» Филологический факультет МГУ имени М.В. Ломоносова, Zbornikradovastr. 322-323, Москва, Russia 24-26. марта 2009(b) г.

[10] S. Hilcenko, "Two Examples of Methodology for Working with Multimedia Educational Software in the Primary School 1st Grade", University of Rzeszow, The Institute of Technology, Department of Didactics of Technology and Computer Science, VIIth International Scientific Conference, Education - Technology - Computer Science, Iwonicz Zdrój, Antologija radova, tom XII, str. 61-69, Poland, 22th-23th September 2009(c)

[11] S. Hilčenko, "The power of the Message", International Conference of Education, Research and Innovation (ICERI 2009), virtual publication (CD), Madrid, Spain, 16th, 17th and 18th of November, 2009(d)

[12] S. Hilčenko, "Multimedia Omnibus - Or five Didactic / Methodical Examples of the Applicaton PCs in Elementary Schoolrooms", SirIKT 2010, Interlacing Education and Research with ICT, Zbornik radova, str. 65-73, Kranjska Gora, Slovenia, from 14th to 17th April 2010(a)

[13] S. Hilčenko, "Model preventivno-korektivnog softvera na primjeru nepravilnosti i poremećaja u pisanju brojeva", Informatologija 2010, Vol. 43, br. 1, str. 63-67, Zagreb, 2010(b) (http://hrcak.srce.hr/)

[14] S. Hiltschenko, "Reflections of a Teacher about the Study of Geometrical Shapes Through an Animation Movie in Primary School (Year 1 to 4)", "International Year of Youth", May 5th and 6th 2011, Faculty of Education/University of Education, Maribor, 
Slovenija and Elementary School Ruše, Slovenia 2011. Beiträge zum "Internationalen Jahr der Jugend", Internationale monographie, Austria: Forschung und Wissenschaft, Erziehungwissenschaft, Band 11, LIT, seite, 64-69

[15] S. Hilčenko, "Jedno rešenje obrazovnog računarskog softvera u nastavnom predmetu svet oko nas", Iskanja - naučno-stručna, revija za edukaciju, str. 84-93, Zavod Republike Slovenije za šolstvo, Sovenija, leto 30, števika 43, 44, januar. 2012(a)

[16] S. Hilcenko, "Tablica množenja u 2. razredu - od igre do računara", University of Rzeszow, The Institute of Technology, Department of Didactics of Technology and Computer Science, VIIIth International Scientific Conference, Edukacja-TechnikaInformatyka, Iwonicz Zdrój, Scientific Annual No/3/2012/Part 2, p. 223-231, Poland, 18-19. September 2012(b)

[17] S. Hilčenko, "A Pierced Bottle leaks not!?" the Heuristic-branched out e-model of animated "Science School" in Year 4, IOSR Journal of Research \& Method in Education (IOSR-JRME) e-ISSN: 2320-7388,p-ISSN: 2320-737X Volume 1, Issue X (Mar. Apr. 2013), PP 44-49 www.iosrjournals.org

[18] T. Jansen, "Instruktionsdesign und Lernprogrammentwicklung", zbornik radova: Didaktičko dizajniranje za multimedije radno orijentisano profesionalno obrazovanje BB Berlin, 1993 